IRSH 57 (20I2), Special Issue, p. I6 doi:I0.1017/S00208590I 2000764 (C) 2012 Internationaal Instituut voor Sociale Geschiedenis

\title{
Mediating Labour: An Introduction CORRIGENDUM
}

Ulbe Bosma, Elise van Nederveen Meerkerk, AND ADITYA SARKAR

doi: I0.1017/S0020859012000430, Published by Cambridge University Press, 24 August 2012.

The email address for the third author, Aditya Sarkar is incorrect. This should be bhochka2@gmail.com

\section{Reference}

Ulbe Bosma, Elise van Nederveen Meerkerk, and Aditya Sarkar, "Mediating Labour: An Introduction", International Review of Social History, 57 (2012), Special Issue, pp. I-I I. 